УДК 796

DOI https://doi.org/10.26661/2663-5925-2021-2-07

\title{
ІНДИВІДУАЛЬНІ ОСОБЛИВОСТІ ДІТЕЙ ДОШКІЛЬНОГО ВІКУ ЯК ЧИННИК ДИФЕРЕНЦІАЦІЇ ІГРОВОЇ ДІЯЛЬНОСТІ У ФІЗИЧНОМУ ВИХОВАННІ
}

\author{
Пасічник В. М. \\ кандидат наук з фізичного виховання та спорту, дочент, \\ дочент кафедри спортивних та рекреаційних ігор \\ Львівський державний університет фізичної культури \\ імені Івана Боберського \\ вул. Костюшка, 11, Львів, Украӥна \\ orcid.org/0000-0002-6381-1471 \\ vikapaska@gmail.com \\ Еделсв О. С. \\ кандидат наук з фізичного виховання та спорту, доцент, \\ доцент кафедри олімпійського та професійного спорту \\ Херсонський державний університет \\ вул. Університетська, 27, Херсон, Україна \\ orcid.org/0000-0002-7866-0282 \\ edelevalexandr@gmail.com
}

Городинська I. В.

кандидат педагогічних наук, дочент,

доиент кафедри теорії та методики фізичного виховання

Херсонський державний університет

вул. Університетська, 27, Херсон, orcid.org/0000-0002-2111-9161

innagorod1969@gmail.com

Ключові слова: ігрова діяльність, дошкільний вік, індивідуальні особливості.
Актуальність теми дослідження зумовлена тим, що в умовах вибору Україною європейського вектора розвитку освіти однією 3 найбільш актуальних форм організації фізичного виховання дітей $\epsilon$ ігрова діяльність. Використання в дошкільному віці ігрової діяльності, як засобу і форми організації фізичного виховання, забезпечує всебічний розвиток дитини, створює умови для гуманізації педагогічного процесу, перетворює дитину з об'єкта соціально-педагогічного впливу на суб'єкта активної творчої діяльності на основі розвитку внутрішніх мотивів до самовдосконалення. Мета дослідження - охарактеризувати особливості контингенту дітей дошкільного віку як чинника диференціації ігрової діяльності у фізичному вихованні. Використовувалися такі методи дослідження: теоретичний аналіз і узагальнення літературних джерел, індукція та дедукція, абстрагування, порівняння, класифікація та систематизація. Для забезпечення успішного індивідуального розвитку кожної особистості необхідний особистісно орієнтований процес навчання та виховання дітей, особливо в дошкільному дитинстві. За таких обставин значно підвищується роль ігрової діяльності в системі фізичного виховання, потенціал якої у впливі не лише на рухову сферу, а й на духовну, особистісну та соціальну. Водночас необхідний диференційований підхід, який ураховує вік, стан здоров'я, фізичної підготовленості, індивідуальну неповторність дитини, своєрідність ії психіки й особистості. Зазначено, 
що підбір засобів ігрової діяльності у процесі фізичного виховання дітей дошкільного віку залежить від низки найважливіших чинників, зокрема таких, як вік, стать, стан здоров'я та фізичний розвиток, рухова активність дитини, рівень фізичної підготовленості, індивідуально-типологічні особливості та біологічний вік.

\title{
INDIVIDUAL FEATURES OF CHILDREN OF PRESCHOOL AGE AS A FACTOR OF DIFFERENTIATION OF GAME ACTIVITY IN PHYSICAL EDUCATION
}

\author{
Pasichnyk V. M. \\ Candidate of Sciences in Physical Education and Sports, Associate Professor, \\ Associate Professor at the Department of Sports and Recreational Games \\ Lviv State University of Physical Culture named after Ivan Boberskyj \\ Kosciuszko str., 11, Lviv, Ukraine \\ orcid.org/0000-0002-6381-1471 \\ vikapaska@gmail.com \\ Edeliev O. S. \\ Candidate of Sciences in Physical Education and Sports, Associate Professor, \\ Associate Professor at the Department of Olympic and Professional Sports \\ Kherson State University \\ University str., 27, Kherson, Ukraine \\ orcid.org/0000-0002-7866-0282 \\ edelevalexandr@gmail.com
}

\author{
Horodinska I. V. \\ Candidate of Pedagogical Sciences, Associate Professor, \\ Associate Professor at the Department of Theory and Methods \\ of Physical Education \\ Kherson State University \\ University str., 27, Kherson, Ukraine \\ orcid.org/0000-0002-2111-9161 \\ innagorod1969@gmail.com
}

Key words: game activity, preschool age, individual features.
The relevance of the research topic is due to the fact that in terms of Ukraine's choice of the European vector of educational development, one of the most relevant forms of organization of physical education of children is play. The use of play activities in preschool as a means and form of organization of physical education, provides comprehensive development of the child, creates conditions for humanization of the pedagogical process, transforms the child from the object of socio-pedagogical influence into a subject of active creative activity based on internal motives self-improvement. The aim of the study was to characterize the features of the contingent of preschool children as a factor in the differentiation of play activities in physical education. The following research methods were used: theoretical analysis and generalization of literature sources, induction and deduction, abstraction, comparison, classification and systematization. To ensure the successful individual development of each individual requires a person-centered process of education and upbringing of children, especially in preschool childhood. Under such circumstances, the role of play activities in the system of physical education increases significantly, the potential of which is not only in the impact on the motor sphere, but also 
on the spiritual, personal and social. This requires a differentiated approach that takes into account the age, health, physical fitness, individual uniqueness of the child, the uniqueness of his psyche and personality. It is noted that the selection of means of play in the process of physical education of preschool children depends on a number of important factors, such as age, gender, health and physical development, physical activity of the child, level of physical fitness, individual typological features and biological age.

Постановка проблеми. Фундаментальні зміни, що відбуваються в сучасному культурноосвітньому просторі, суспільні запити і потреби утверджують думку про пріоритет дитинства як найвідповідальнішого періоду становлення особистості. Саме в дошкільному віці відбувається становлення особистості дитини, формування ii фізичної та духовної культури - основи гармонійного розвитку, як краси людської душі та здорового тіла. Сьогодні одним 3 основних завдань удосконалення дошкільної освіти є виховання гармонійно розвинутої, довершеної, здорової дитини, здатної цілком реалізувати свої духовні, фізичні, інтелектуальні та моральні можливості [14].

Важливим напрямом фізичного виховання дітей дошкільного віку є використання різноманітних форм i засобів для їх гармонійного розвитку, серед яких важливе місце відводиться ігровій діяльності [11]. Серед специфічних дитячих форм діяльності гра стоїть на першому місці. Виділені програмою «Я у світі» сім ліній розвитку дошкільника пов'язані з ігровою діяльністю, що спонукає до їі поширеного використання.

За твердженням науковців, використання в дошкільному віці ігрової діяльності як засобу i форми організації фізичного виховання забезпечує всебічний розвиток дитини, створює умови для гуманізації педагогічного процесу, перетворює дитину з об'єкта соціально-педагогічного впливу на суб'єкта активної творчої діяльності на основі розвитку внутрішніх мотивів до самовдосконалення [5].

Для забезпечення успішного індивідуального розвитку кожної особистості необхідний особистісно орієнтований процес навчання та виховання дітей, особливо в дошкільному дитинстві.

За таких обставин значно підвищується роль ігрової діяльності в системі фізичного виховання, потенціал якої у впливі не лише на рухову сферу, а й на духовну, особистісну та соціальну. Дослідники відзначають наявність взаємозв'язку між інтелектуальним, моральним, емоційним, соціальним розвитком і руховою діяльністю, станом здоров'я дитини [2; 16-18]. Водночас необхідний диференційований підхід, який ураховує вік, стан здоров'я, фізичної підготовленості, індивідуальну неповторність дитини, своєрідність їі психіки й особистості.

Метастатті-охарактеризуватиособливостіконтингенту дітей дошкільного віку як чинника диференціації ігрової діяльності у фізичному вихованні.
У роботі використовувалися такі методи дослідження: теоретичний аналіз і узагальнення літературних джерел, індукція та дедукція, абстрагування, порівняння, класифікація та систематизація.

Виклад основного матеріалу. Підбір засобів ігрової діяльності у процесі фізичного виховання дітей дошкільного віку залежить від низки найважливіших чинників, зокрема від індивідуальних особливостей (особливості контингенту) (рис. 1).

Так, за віком учасників ми розподілили їх на 6 груп:

- молодший дошкільний вік (3-4 роки);

- середній дошкільний вік (4-5 років);

- старший дошкільний вік (5-6 років);

- змішана, дошкільний вік (3-6 років);

- молодший-середній дошкільний вік (3-5 років);

- середній-старший дошкільний вік (4-6 років).

Проведення різноманітних ігор із дітьми різних вікових груп має свою специфіку, яка залежить від анатомо-фізіологічних і психологічних особливостей дошкільнят.

Для дітей молодшого дошкільного віку підбирають ігри з нескладним змістом, із простим i доступним сюжетом, у яких дійові особи добре відомі дитині з повсякденного життя або з якими iii легко познайомити за допомогою картинки, іграшки, казки. Правила в цих іграх дуже прості, їх небагато, вони тісно пов' язані із сюжетом, невелика і кількість ролей. Ігри добираються з обов'язковим чергуванням руху і відпочинку, оскільки в цьому віці дитина погано володіє своїми рухами. Необхідно привчати малят гратися разом невеликими групами за допомогою різноманітних іграшок, м'ячів, обручів. Водночас можна починати проводити колективні ігри із простим змістом i характером руху, об'єднувати більшу кількість дітей, які виконують ті самі рухи. Бажано, щоб ігри супроводжувались віршовим текстом, який виголошує педагог, а діти наслідують дії, про які в ньому розповідається. У дітей цього віку ще немає зацікавленості в результаті гри, їх приваблює сам процес руху. Значне місце в цій віковій групі належить ігровим вправам. У них включаються прості рухові завдання: принести прапорець, наздогнати м'яч, знайти предмет тощо. Рухи мають бути відомі і доступні дітям (ходьба, біг, катання м'ячів) [2].

Поступово ігрову діяльність ускладнюють різноманітними рухами (підлізання, стрибки, ловлення та підкидання м'яча). Основне завдання в 
цей період - зберігати руховий досвід дошкільнят, удосконалювати набуті ними рухові навички. Поступово вводяться нові ігри, а вивчені раніше проводяться в ускладненому варіанті. Тривалість гри для дітей молодшого дошкільного віку становить у середньому 5-8 хв, 3 повторенням кожної 3 них $3-5$ разів [2].

У дітей середнього дошкільного віку накопичується руховий досвід, рухи стають більш координованими, відповідно ускладнюються умови проведення гри (збільшується відстань для бігу, метання, висота стрибків, відстань лазіння тощо), правила і взаємодії дітей. У цій віковій групі педагог уже розподіляє ролі серед дітей у грі. Якщо гра становить певні труднощі, то іiі краще проводити 3 меншою кількістю учасників. Як і в молодшій групі, широкого використання набувають сюжетні ігри, водночас педагог використовує образну розповідь. Крім того, 3 дітьми проводять хороводи, у яких поєднуються рухові дії, слово, пісня, ритм. Надмірна рухливість дітей цього віку та їхне невміння раціонально використовувати свої сили вимагають особливого підходу в дозуванні ігор. Вихователь та інструктор із фізичної культури стежить, щоб рухи чергувались із короткочасним відпочинком. Загальна тривалість гри дошкільнят цієї групи 8-10 хв, кількість повторень - 3-6 разів [2; 8].

У дітей старшої групи руховий досвід більший, що дає можливість використовувати в іграх складніші рухи. Наприклад, біг зі зміною темпу, кидання та ловіння м'яча, стрибки. У цьому віці велике значення мають ігри із застосуванням різноманітних предметів: м'ячів, обручів, скакалок, стрічок. Можна проводити ігри, у яких ігрова діяльність передбачає вибір із кількох варіантів одного правильного, протиборства та забави зі швидким пісенним темпом. 3 великою зацікавленістю діти грають в ігри, у яких передбачається розподіл на підгрупи. Вони привчають в інтересах своєї команди добиватись перемоги, виявляти рішучість, спритність, витримку. Важливий момент у керівництві грою - дозування рухів, особливо в іграх з бігом, лазінням, стрибками. Тривалість безперервного бігу зі швидкістю вище середньої для дошкільнят цієї групи становить 30-40 с за одне повторення гри, загальна тривалість - до 10-15 хв. Кількість повторень залежить від іiї змісту, але не повинна перевищувати 4-6 разів. Між повтореннями - короткі паузи для відпочинку. Загальна тривалість рухливої гри - 10-12 хв. У цій віковій групі дітей цікавить не тільки зміст гри і роль у ній, а й результати (швидше всіх пробігти, влучити в ціль). Тому бажано проводити якомога більше ігор з елементами змагання на спритність, влучність, швидкість рухів тощо. Під час проведення ігр з елементами змагань дітей привчають бути стриманими, уникати сварок, прагнути до того, щоб ігри сприяли вихованню в них позитивних рис характеру. Важливо навчити дітей самостійно розповідати зміст знайомої їм гри, пояснювати іiі правила, аналізувати. Вони повинні вміти самі організувати і провести рухливу гру з нескладними правилами [2;9].

У зв'язку з тим, що склад дітей у мішаній групі різновіковий (3-6 років), це потребує від педагога врахування програмових вимог для кожної вікової підгрупи, творчого підходу до підбору методів та прийомів ігрової діяльності, постійної уваги до психолого-фізіологічних особливостей дошкільнят.

Перебування в одній групі дітей різного віку має багато плюсів: дитині простіше перейняти навички діяльності в іншої дитини, ніж у дорослого, тому молодші діти в таких групах швидше розвиваються і засвоюють програму навчання. Старші діти відчувають відповідальність за молодших, розуміють, що $є$ прикладом для наслідування, це сприяє поліпшенню особистісних характеристик. Спілкування молодших дітей зі старшими створює сприятливі умови для формування «випереджальних» знань і взаємного навчання.

В об’єднавчій групі в разі добре організованого просторово-освітнього середовища, гра дає більший позитивний ефект, ніж в одновіковій. Значною мірою наявний самостійний і взаємонавчальний компонент. Вихователь організовує і грає 3

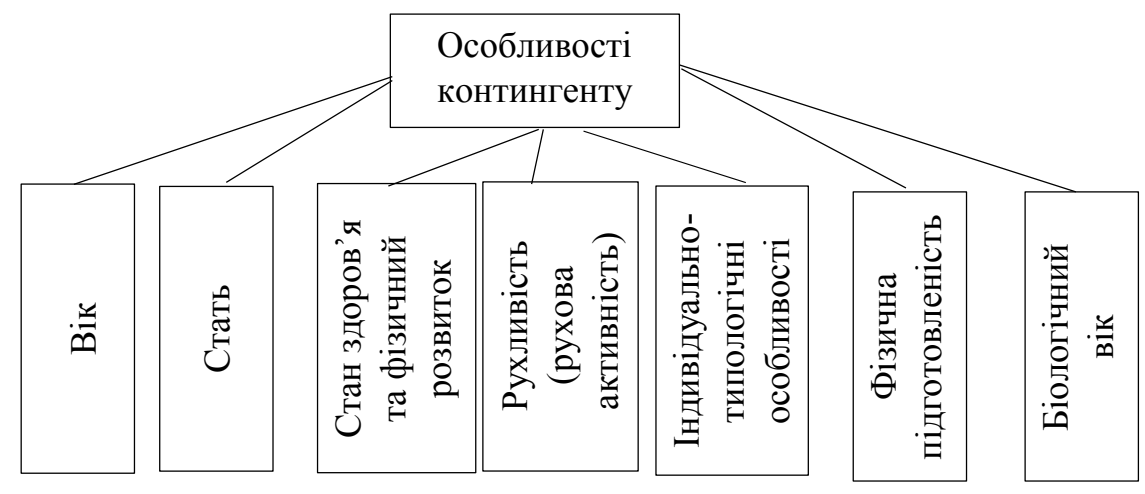

Рис. 1. Особливості контингенту дітей дошкільного віку 
дітьми, дошкільнята, беручи участь у грі, отримують нові знання або закріплюють уже вивчене.

Будь-яка гра підбирається з урахуванням тієї умови, щоб у ній брали участь водночас молодші, середні та старші дошкільники, вона була цікавою для них. У сюжетних іграх головну роль виконує хто-небудь із старших дітей. Оскільки рухова підготовка старших дошкільників краще, під час гри їм треба ускладнювати рухове завдання.

У разі проведення ігор естафетного характеру з дітьми 3-6 років їх розподіляють на рівні за можливостями команди, щоб у кожній із них були старші та молодші діти. Складність організації ігрової діяльності в таких групах у тому, що потрібно враховувати диференціацію навчального та фізичного навантаження для дітей різного віку.

Найбільш вдалим є об'єднання дітей двох суміжних вікових груп. Доцільно під час організації ігрової діяльності у процесі фізичного виховання об'єднувати дітей молодшої та середньої або старшої та середньої груп, у яких програмні вимоги не мають значної різниці. Водночас звертається увага на специфіку програмового змісту 3 розвитку основних рухів (стрибки, лазіння, метання тощо). Вона полягає в тому, що програмові вимоги ускладнюються в основному завдяки якісним і кількісним показникам у виконанні фізичних вправ. Тому під час проведення ігор планують для обох вікових підгруп ті самі види основних рухів, однак із різними вимогами щодо ix виконання. Це забезпечує активність дітей, інтерес до запропонованих рухів і оптимальну моторну щільність заняття [2; 8-9].

Підбір фізичних вправ для ігор роблять 3 урахуванням можливостей дітей, які переважають за кількісним складом у мішаній групі. Наприклад, якщо у групі дошкільнят 3-5 років більше молодших дітей, фізичні вправи підбираються з урахуванням програми для молодшої групи. Однак для дітей середнього віку вправи ускладнюються і обов'язково підвищуються вимоги до якості їх виконання. 3'являється можливість для обміну ігровим досвідом - та сама можливість, яка не може розвиватися в одновікових групах із постійним складом дітей та набором звичних ігрових сюжетів.

У різновікових групах можна проводити заняття різного типу: ігрового, сюжетно-ігрового і тренувального. Заняття ігрового типу відрізняються тим, що вони включають добре знайомі всім дітям рухи. В іграх закріплюються рухові навички, відбувається розвиток фізичних якостей. Сюжетно-ігрове заняття будується на цілісній сюжетно-ігровій ситуації, що відображає в умовній формі навколишній світ дитини. Заняття складається 3 різних видів основних рухів та ігрових вправ загальнорозвивального імітаційного характеру. Цей тип заняття підвищує інтерес дітей до різних рухів. Тренувальне заняття спрямоване на розвиток рухових можливостей дітей, воно включає розмаїття циклічних, ритмічних рухів, ігрові вправи на розвиток швидкості рухів, спритності та витривалості. Варто врахувати знання і руховий досвід старших дітей, дати їм можливість використовувати показ фізичних вправ для молодших, заохочувати прагнення дітей передавати свій руховий досвід, доручати дітям старшої підгрупи пояснити гру, виконувати роль ведучих, створювати ігрову обстановку, а також їхню участь у розстановці та прибиранні фізкультурних посібників.

За тендерною ознакою виділяються:

- ігри для дівчаток;

- ігри для хлопчиків;

- об'єднавчі ігри (для хлопчиків і дівчаток).

Питання про гендерне виховання нині почало набувати актуальності, і все більше педагогів i психологів стали замислюватися про необхідність диференційованого підходу до виховання дівчаток і хлопчиків, починаючи вже 3 дошкільного віку. Річ у тому, що до кінця раннього віку дитина засвоює свою статеву приналежність, а до 7 років у неї формується гендерна стійкість, тобто усвідомлення того, що приналежність до статі зберігається незалежно від ситуації і бажань дитини [6].

Труднощі в наданні диференційованого підходу за ознакою статі зумовлені тим, що тривалий час у процесі фізичного виховання дошкільнят, як і в усьому дошкільному вихованні, найчастіше орієнтувалися на «умовну» дитину, а не на хлопчика або дівчинку. Різниця між хлопчиками і дівчатками виявлялася тільки під час відстеження ефективності фізичної підготовки - стандарти для опанування основних типів рухів і мали градацію за статтю.

Але гендерний принцип дає змогу відійти від традиційного «середньостатевого» фізичного виховання дітей конкретної вікової групи та максимально використати можливості фізичної культури для розвитку мужності у хлопчиків та жіночості в дівчаток. Це передбачає методичну почерговість занять (фрагментів занять) з роз'єднувальною тенденцією на відокремлення в рухах хлопчиків та дівчаток із поєднанням мужнього та жіночого в парних рухово-ігрових діях, заздалегідь передбачених педагогом у плані-сценарії $[3 ; 6]$.

Гендерні особливості проявляються в таких типах взаємин дітей дошкільного віку, як: 1) взаємини 3 дорослими; 2) взаємини 3 однолітками своєї статі; 3) взаємини з однолітками іншої статі; 4) взаємини із самим/самою собою.

Характерними ознаками гендерних особливостей хлопчиків і дівчаток дошкільного віку, що впливають на формування дружніх відносин, $\epsilon$ те, що у хлопчиків у структурі дружніх відносин домінують емоційний і когнітивний компоненти, у дівчаток - емоційний і поведінковий. Ставлення 
до однолітків протилежної статі у хлопчиків і дівчаток складаються по-різному: для дівчаток активно-позитивний i нестійкий, для хлопчиків більш характерні активно-позитивний, пасивно-позитивний і егоїстичний типи. У хлопчиків спостерігається поступове зниження активності i наростання нестійкості у відносинах із дівчатками. У дівчаток із дорослішанням активність у стосунках із хлопчиками значно підвищується: відносини дівчаток стають більш ініціативними, зацікавленими та стійкими [1].

В основі гендерного підходу лежить моральне виховання, спільні цілі якого однакові для представників обох статей, але особистісні якості хлопчиків і дівчаток диференційовані. Метою гендерного підходу є виховання дітей різної статі, однаково здатних до самореалізації і розкриття своїх потенціалів і можливостей у сучасному суспільстві. Головні завдання гендерного виховання в ігровій діяльності: формувати в дітях якості мужності і жіночності; готувати їх до виконання в майбутньому відповідних статі соціальних ролей; виховувати культуру взаємин між хлопчиками і дівчатками; диференційованого виховання, що передбачає індивідуальний підхід, заснований на психічних і фізичних особливостях статі дитини, на вихованні шанобливого ставлення до дітей протилежної статі й один до одного, розширення кругозору і збільшення обсягу знань дітей про зміст соціальних ролей чоловіка та жінки [3].

Отже, в організації ігрової діяльності у процесі фізичного виховання дітей потрібно застосовувати не лише біологічний підхід, що грунтується на статевому диморфізмі, який зумовлює диференціювання фізичних навантажень і рівня фізичної підготовленості, а й гендерний підхід, який припускає, що різниця в поведінці, сприйнятті, ціннісних орієнтаціях хлопчиків і дівчаток визначається не стільки фізіологічними особливостями, скільки соціалізаційними механізмами, вихованням і культурними традиціями.

Залучення дітей до всіх організаційних форм і заходів фізкультурно-оздоровчої роботи, зокрема до ігрової діяльності, у ЗДО базується насамперед на даних вивчення індивідуальних особливостей стану здоров'я і фізичного розвитку кожної дитини, яке проводиться в закладі дошкільної освіти під час медичних оглядів дітей. На основі цих даних з урахуванням висновків лікарів за місцем проживання, лікування, медичного консультування дітей лікар і медична сестра дошкільного закладу розподіляють вихованців за медичними групами (групи здоров'я), фіксують висновки і рекомендації щодо участі дітей у фізкультурно-оздоровчих заходах, формах освітньої роботи 3 фізичного розвитку і виховання в індивідуальних медичних картках та доводять їх до відома батьків вихованців і педагогів. Залежно від встановленої медичної групи й індивідуальних призначень вихователі, інструктори 3 фізичної культури і плавання забезпечують відповідний ступінь участі кожної дитини в системі фізкультурно-оздоровчої роботи, оптимальний рівень фізичних, психічних, емоційних навантажень для неї. Під час обстеження фізичного розвитку враховуються антропометричні показники: довжина та маса тіла, окружність грудної клітки та голови. Отримані дані порівнюються 3 оціночними таблицями фізичного розвитку дітей (стандартами для даного регіону). На основі комплексного медичного обстеження (органів дихання, серцево-судинної системи тощо) діти розподіляються за станом здоров'я на три групи [7]:

- перша група - здорові діти, які не мають відхилень за всіма ознаками здоров'я, не хворіють у період спостереження або мають незначні одиничні відхилення, які не впливають на стан здоров'я і не потребують корекції;

- друга група - діти 3 ризиком виникнення хронічної патології та ті, які часто хворіють (4 i більше разів на рік), також це діти $з$ функціональними відхиленнями, зумовленими ступенем морфофізіологічної зрілості органів та систем;

- третя, четверта, п’ята група - діти із хронічною патологією у стадії компенсації.

3 огляду на стан здоров'я та фізичний розвиток дітей дошкільного віку розподіляють на три групи фізичного виховання.

До основної групи зараховують дітей із хорошим станом здоров'я, що відповідає віковим нормам психомоторного розвитку, а також із незначними відхиленнями у стані здоров'я та достатньою фізичною підготовленістю. Ці діти беруть участь у всіх формах фізичної культури відповідно до програми.

До підготовчої групи зараховують дітей із відставанням у фізичному розвитку та достатньою фізичною підготовленістю (діти-реконвалесценти). Такі діти частіше хворіють катарами, 3 перезбудженою нервовою системою, 3 функціональною затримкою розвитку нервової системи. Заняття 3 фізичної культури для таких дітей проводять згідно із програмою, але 3 обов'язковим дотриманням принципів поступовості та наступності. Вихованці, які віднесені до цієї групи, виконують усі фізичні вправи, за винятком тих, що викликають значні фізичні напруження (лазіння по канату, у стрибках у довжину та висоту з розбігу зменшується кількість повторення).

До третьої групи (спеціальна) відносять дітей, які мають значні відхилення у стані здоров'я тимчасового або постійного характеру. Заняття 3 фізичної культури $з$ ними проводять за спеціально розробленими програмами. Вихованцям, 
віднесеним до цієї групи, обмежують вправи на швидкість, силу та витривалість, зменшують час або дистанцію бігу тощо. Під час проведення різних форм фізичної культури вони потребують обов'язкового індивідуального підходу.

Розподіл дітей на медичні групи кожні півроку переглядається. Якщо в дитини підготовчої медичної групи стан здоров'я покращується, іiї переводять в основну групу. Або навпаки, після захворювання дитина з основної групи тимчасово переводиться до підготовчої.

Ще один критерій диференційованого підходу до дітей у процесі фізичного виховання - це рівень рухової активності. Рухова активність один із чинників, що впливає на стан здоров'я і працездатність дитини. Невідповідність режиму рухової активності віковим фізіологічним можливостям і потребам дітей призводить або до гіподинамії, або до гіперкінезії, що може спричинити негативні зміни в дитячому організмі.

Рухова активність дітей дошкільного віку має яскраво виражені індивідуальні особливості, що в основному визначається індивідуально-типологічними особливостями нервової системи та фізичного розвитку, ступенем самостійності, стійкістю інтересів до певних ігор, педагогічними впливами тощо. Діти дошкільного віку мають різні фізичні можливості, умовно, незалежно від віку виділяють три групи дітей, які характеризуються великою, середньої і малої рухливістю. Кожній підгрупі дітей притаманна деяка схожість рівнів обсягу, тривалості й інтенсивності рухової активності [13].

Діти з великою рухливістю відрізняються високою реактивністю, неврівноваженістю поведінки, вони частіше за інших потрапляють у конфліктні ситуації. Через надмірну рухливість такі діти не завжди встигають зрозуміти суть гри, у результаті чого в них відзначається невисокий ступінь усвідомлення своїх дій. Зазвичай вони добре виконують прості вправи, але уникають рухів, що вимагають точності та зосередженості, стриманості поведінки. Такі діти не відзначаються достатньою спритністю та координацією рухів, рухи їхні різкі, швидкі, часто не приносять користі. Діти цієї групи відрізняються підвищеною психомоторною збудливістю, гіперактивністю. Їм властиві рухове розгальмування, метушливість, занепокоєння, нестриманість і дратівливість. У них слабко сформовані механізми саморегуляції діяльності й поведінки. Підвищена інтенсивність гри викликає стомлення, щопозначаєтьсяназагальнійповедінці.

Діти середньої рухливості відрізняються найбільш рівною, спокійною поведінкою, помірною рухливістю. Зазвичай діти цієї групи мають високі та середні показники фізичної підготовленості й добрий рівень розвитку рухових якостей.
Вони врівноважені, емоційні, азартні, зазвичай упевнені, чіткі, цілеспрямовані. Такі діти самостійно вибирають ігри та фізкультурне обладнання, зазвичай $€$ ініціаторами колективних ігор. Для дітей із середнім рівнем рухової активності характерна різноманітна рухова поведінка під час ігрової діяльності. Вони уважні впродовж усього фізкультурного заняття i точно виконують усі запропоновані завдання, аналізують кожну свою дію, з великим інтересом ставляться до різноманітної ігрових засобів [13].

Діти третьої групи мають низький обсяг рухової активності, поєднаний 3 низькими та середніми показниками тривалості й інтенсивності. Малорухливі діти мляві, пасивні, швидко втомлюються, намагаються піти в бік, що б нікому не заважати, вибирають діяльність, яка потребує великого простору. У всіх дітей цієї групи спостерігається відставання показників розвитку основних форм рухів та фізичних якостей. Такі діти не наважуються вступати в контакт з однолітками, тому вони потребують постійної допомоги дорослих. Цей недолік у поведінці дитини найчастіше пояснюється слабким руховим досвідом, зумовленим патологією і сформованою звичкою до малорухливого способу життя.

Спостереження [13] показали, що наявний тісний зв'язок між основними показниками рухової активності та поведінкою дітей упродовж дня, характером їхньої рухової діяльності.

Для реалізації диференційованого підходу у процесі ігрової діяльності можна дітей розподілити на три основні підгрупи залежно від рівня рухової активності. Однак такий розподіл не дуже зручний у практичному використанні, тому в умовах групового виховання доцільно розподіляти дітей на дві підгрупи, з урахуванням стану здоров'я, рівня фізичної підготовленості та рухової активності. До першої підгрупи входять діти першої групи здоров'я, які мають середній і високий рівні рухової активності й добру фізичну підготовленість. До другої підгрупи належать діти другої та третьої груп здоров'я, з низьким рівнем рухової активності та низьким рівнем фізичної підготовленості.

Коли педагог організовує ігрову діяльність, він має брати до уваги ступінь рухливості кожної дитини і регулювати ії (вчасно зупинити одну, активізувати іншу, підібрати третій відповідну роль тощо). За допомогою різних педагогічних прийомів можна домогтися поступового залучення малорухливих дітей до активної ігрової діяльності, а також переходу дітей із високою інтенсивністю рухової активності від активної до більш спокійної ігрової діяльності. Для кожної підгрупи підбираються різні ігри й ігрові вправи з основних рухів. Так, дітям із високим рівнем рухової актив- 
ності варто пропонувати завдання на розвиток уваги, координації рухів, спритності, які вимагають точності виконання дій. Цим дітям необхідні рухи, які сприяють розвитку окоміру, сили і точності кидка. Дітям із низьким рівнем рухової активності - на розвиток швидкості рухів і витривалості, на швидке переключення 3 одного виду на інший. Дітям із середнім рівнем рухової активності ставлять більш високі вимоги до якості виконання рухів, підбирають варіативні завдання [13].

Індивідуальна неповторність дитини, своєрідність їі психіки й особистості проявляються в рисах темпераменту, характеру, у специфіці інтересів, як пізнавальних процесів.

Підбір засобів ігрової діяльності в дошкільному віці залежить від низки найважливіших чинників, зокрема від індивідуальних особливостей нервової системи дитини. Вибір темпераменту як основи оцінки індивідуальних відмінностей дитини обгрунтований і ефективний. По-перше, особливості типів темпераменту досить просто фіксують за результатами спостереження, вони проявляються в поведінці і діяльності дітей. По-друге, темперамент $є$ фундаментальною характеристикою людини, він стійкий, зумовлений вродженими особливостями властивостей нервової системи і мало схильний до змін під дією середовища і виховання. По-третє, темперамент дитини проявляється в усіх сферах психічної і фізичної активності, оскільки його психофізіологічними компонентами $є$ активність і емоційність [12].

Оскільки тип темпераменту $є$ вродженою якістю, з ним треба починати працювати якомога раніше, сприятливим періодом для такої роботи є дошкільний вік. Саме тому у процесі ігрової діяльностідітейдошкільноговікунеобхідновраховувати властивості панівних типів їхніх темпераментів.

У дошкільнят-холериків треба намагатися розвивати гальмівний процес, виробляти вміння гальмувати себе, свої імпульсивні реакції. Від цих вихованців треба наполегливо вимагати спокійних, нерізких рухів, виховувати стриманість у виконанні рухів під час ігрової діяльності, правильну послідовність дій. Енергію і активність, розумну ініціативність холерика варто заохочувати під час жвавих ігор. Важливо запобігти перезбудженню дитини-холерика, домагатися від неї стриманої поведінки, давати їй можливість реалізувати потребу в руховій активності. Необхідно розвивати в таких дітей альтруїзм, почуття справедливості, увагу до почуттів інших людей. Корисно давати холерику завдання, які деякою мірою перевищують його сили і здібності, що сприятиме його стриманості $[12 ; 15]$

Що стосується дітей-меланхоліків, то у відносинах із ними необхідні м'якість, тактовність, чуйність і доброзичливість, оскільки надмірна суворість ще більше загальмовує їх і призводить до зниження працездатності. Необхідно давати їм можливість більше діяти і проявляти активність в іграх. Водночас необхідно дотримуватися поступовості у тренуванні працездатності, пам'ятати про те, що стомлення в таких дітей настає швидше. Варто частіше заохочувати таких дітей, підтримувати в них позитивну самооцінку і позитивні емоції, висловлювати впевненість у їхніх силах, створювати ситуації успіху, розвивати активність і сміливість, вимагати вчинків, пов'язаних iз подоланням труднощів. Необхідно допомагати дитині вільно почуватися в колективі однолітків, що сприятиме впевненості в собі і товаристві.

У флегматика треба розвивати велику рухливість, активність, не допускати, щоб він проявляв байдужість до ігрової діяльності, млявість, інертність. Варто більше активізувати діяльність дітей-флегматиків, частіше стимулювати таких дітей до рухової активності у грі в певному темпі. В організації ігор із флегматиками необхідно враховувати їхню схильність до бездіяльності, постійно активізувати їхню рухову активність, звертати особливу увагу на активізацію уяви, пробуджувати їхню думку, що сприятиме меншій пасивності [12; 15].

У сангвініка варто розвивати вольові якості, виховувати витримку і зосередженість уваги, не допускати поверхневого, недбалого виконання ним рухів в ігровій діяльності, необхідно вимагати від дитини доводити почату справу до кінця. Під час організації уваги дитини-сангвініка, навчання його різних способів виконання якоїсь дії педагог повинен зосереджувати увагу сангвініка у грі спочатку на короткий, а потім на тривалий час. Це робить сангвініка старанним у роботі. Сангвініку необхідно звертати увагу на організацію його діяльності $[12 ; 15]$.

В об'єднанні дітей у групи, команди для проведення ігор педагог ураховує індивідуальні особливості дітей, формує команди дітей, рівних за силами, для активізації невпевнених, сором'язливих дітей об'єднують зі сміливими й активними.

Тому, беручи до уваги всі ці чинники, для педагогів та інструкторів 3 фізичної культури дуже важливо враховувати індивідуально-типологічні особливості саморегуляції діяльності та поведінки дітей. Урахування індивідуально-типологічних особливостей дошкільнят у процесі безпосередньо ігрової діяльності передбачає не зміну типу темпераменту дитини (що практично неможливо), а використання оптимальних шляхів формування саморегуляції поведінки і діяльності відповідно до особливостей типу нервової системи / темпераменту вихованців. Власне необхідно врахувати вікові особливості прояву психологічних властивостей темпераменту дітей дошкільного 
віку різних вікових груп, допомагати дітям відповідно $з$ їхньою вікової специфікою впоратися 3 негативними проявами кожного темпераменту, сприяти розвитку позитивних аспектів темпераменту, виробляти вміння володіти своїм темпераментом у процесі ігрової діяльності.

Своєчасна та поглиблена діагностика фізичної підготовленості дозволяє виявити рівень розвитку рухів і фізичних якостей у дитини, а також ступінь його відповідності віковим нормам. Загалом, ступінь фізичної підготовленості можна визначити як відповідність рухових умінь і навичок дитини нормативним вимогам, закладеним у реалізованій дошкільним закладом програмі. Залежно від кількісних і якісних даних характеризують рівень фізичної підготовленості дітей тієї чи іншої групи, можлива корекція планів фізкультурно-оздоровчої роботи в частині змісту фізичних вправ, регулювання фізичного навантаження, зміна умов організації навчання дітей рухів і самостійної рухової діяльності дітей.

Результати тестування дітей допомагають вивчити особливості їхнього моторного розвитку, нерівномірності в розвитку рухових функцій дітей, що дає змогу визначити причини відставання або випередження та намітити необхідні педагогічні прийоми в застосуванні засобів ігрової діяльності для корекції рівня фізичної підготовленості [10].

Для цього використовуються діагностичні тести у вигляді контрольних рухових завдань, які пропонують дітям в ігровій формі [10]. Ці тести відзначаються доступністю виконання, не вимагають підготовки вихователя та складного обладнання для їх проведення.

Дітей, які виконали більшість тестів із результатами в рамках вікових норм, можна віднести до середнього рівня фізичної підготовленості; вище орієнтованих показників (більше 3-4 показників) - до високого рівня фізичної підготовленості. Якщо з усіх тестів дитина має від п'яти і більше показників, нижчих за норму, то в неї низький рівень фізичної підготовленості.

Кожний період має свої особливості розвитку, властиві кожній віковій групі. Крім вікових періодів, так званий «паспортний» і біологічний вік. Розвиток організму відбувається безперервно, межі вікових періодів умовні. Тому чіткої границі між віковими групами не визначається. Однак, крім календарного, так званого «паспортного» віку, дуже важливо знати біологічний (фізіологічний) вік. Він характеризується певним рівнем фізичного розвитку, руховими можливостями, окостенінням скелета, розвитком зубів. Календарний вік може часто не збігатися з біологічним. Якщо фізичний розвиток дитини добрий, то біологічний вік випереджає паспортний, якщо слабий, то біологічний вік відстає від паспортного [4].

Значення біологічного віку важливе для правильного визначення працездатності, рухових якостей, характеру і рівня пристосувальної реакцій на різноманітні навантаження. Критеріями біологічного віку можуть бути різноманітні морфологічні та біохімічні показники. У дошкільному віці біологічну зрілість визначають за трьома показниками [4]: кількість постійних зубів у різних стадіях їх прорізання; величина співвідношення окружності голови до довжини тіла; зріст дитини співвідноситься з віково-статевими нормативами.

Визначення біологічного віку у сукупності 3 показниками фізичного розвитку дозволяе більш точно оцінювати рівень функціональних можливостей основних систем організму, який зростає, і деякою мірою рівень здоров'я дитини. Визначення відповідності біологічного віку паспортному є важливим також у зв'язку з необхідністю оптимального планування педагогічних впливів у процесі фізичного виховання. Отже, можна припустити, що біологічний вік може слугувати опосередкованим чинником у диференційованому підході під час вибору засобів ігрової діяльності.

Висновки. У фізичному вихованні дітей різного віку наявність узгодженості у трактуванні основних теоретичних та методичних аспектів ігрової діяльності важлива для нормалізації діяльності всієї системи, забезпечення розв'язання основних завдань навчання та виховання в межах окресленої діяльності тощо. Ця проблема суттєво загострюється, якщо центральне місце в суб'єктно-об'єктних відносинах у фізичному вихованні займають діти дошкільного віку, які мають низку суттєвих відмінностей фізіологічного, функціонального, психоемоційного й інших рівнів. Підбір засобів ігрової діяльності у процесі фізичного виховання дітей дошкільного віку залежить від низки найважливіших чинників, зокрема таких, як вік, стать, стан здоров'я та фізичний розвиток, рухова активність дитини, рівень фізичної підготовленості, індивідуально-типологічні особливості та біологічний вік.

Перспективи подальших досліджень будуть пов'язані з розробленням і обгрунтуванням узагальненої й уніфікованої класифікації ігрової діяльності у фізичному вихованні дітей дошкільного віку. 


\section{ЛІТЕРАТУРА}

1. Берн Ш. Гендерна психологія. Київ : Прайм-Сврознак, 2011. 320 с.

2. Вільчковський Е., Курок О. Теорія і методика фізичного виховання дітей дошкільного віку. Суми : ВТД «Університетська книга», 2008. 428 с.

3. Градусова Л. Гендерная педагогика : учебное пособие. Москва : Флинта ; Наука, 2011. 175 с.

4. Гриньків М., Вовканич Л., Музика Ф. Спортивна морфологія (з основами вікової морфології) : навчальний посібник. Львів : ЛДУФК, 2015. 304 с.

5. Дидактичні ігри з м’ячами : навчальний посібник / авт. кол. : Є. Приступа та ін. Львів : ЛДУФК, 2014. $206 \mathrm{c}$.

6. Кравець В. Гендерна педагогіка. Тернопіль : Джура, 2003. 416 с.

7. Щодо організації фізкультурно-оздоровчої роботи у дошкільних навчальних закладах : лист МОН від 2 вересня 2016 р. № 1/9-456. URL: https://imzo.gov.ua/2016/09/08/list-mon-vid-02-09-2016-1-9-456shhodo-organizatsiyi-fizkulturno-ozdorovchoyi-roboti-u-doshkilnih-navchalnih-zakladah/.

8. Лущик I. Рухливі ігри в дитячому садку. Харків : Основа, 2008. 110 с.

9. Лущик І. Фізичне виховання дошкільників. Фізкультурна й оздоровча робота. Харків : Ранок, 2007. $224 \mathrm{c}$.

10. Методика тестування фізичної підготовленості дітей дошкільного віку : а. с. № 100097 Україна / В. Пасічник та ін. Опубл. 01.10.2020 p.

11. Пасічник В. Сутність ігрової діяльності у формуванні особистості дітей дошкільного віку. Спортивні ігри. 2020. № 3 (17). С. 43-57.

12. Пожарская Л. Как учесть особенности темперамента в учебно-воспитательном процессе. Педагогическая мастерская. Все для учителя. 2015. № 3 (39). С. 6-11.

13. Рунова М. Рухова активність дитини в дитячому садку : посібник для працівників дошкільних закладів, викладачів і студентів педвузів і коледжів. Харків : Ранок, 2007. 192 с .

14. Чаговець А. Гармонійне виховання дітей 4-6 років у культурно-освітньому просторі дошкільного навчального закладу : автореф. дис. ... докт. пед. наук: 13.00.07. Київ, 2019. 39 с.

15. Юрицына Н. Учёт индивидуально-типологических особенностей дошкольников в процессе непосредственно-образовательной деятельности по физическому развитию. Вестник эксnериментальногообразования. 2016.URL:https://cyberleninka.ru/article/n/uchyot-individualno-tipologicheskihosobennostey-doshkolnikov-v-protsesse-neposredstvenno-obrazovatelnoy-deyatelnosti-po/viewer.

16. Effectiveness of integral-developmental balls use in complex development of physical and mental abilities of senior preschool age children / V. Pasichnyk et al. Journal of Physical Education and Sport. 2015. № 15 (4). P. 775-780. DOI: 10.7752/jpes.2015.04118.

17. Prerequisites for the physical development of preschool children for the realization of the tasks of physical education / V. Pasichnyk et al. Physical Activity Review. 2018. № 6. P. 117-126.

18. Physical condition of preschool children with disabilities in psychological and physical development / V. Pasichnyk et al. Journal of Physical Education and Sport. Vol. 21 (1). Art. 33. P. 352-359.

\section{REFERENCES}

1. Bern S.H. (2011) Henderna psykholohiya [Gender psychology]. Kiev: Praym-Yevroznak. (in Ukrainian)

2. Vil'chkovs'kyy E.S., Kurok O.I. (2004) Teoriya i metodyka fizychnoho vykhovannya ditey doshkil'noho viku [Theory and methods of physical education of preschool children]. Sumy: VTD "Universytets'ka knyha". (in Ukrainian)

3. Gradusova, L.V. (2011) Gendernaya pedagogika [Gender pedagogy]. Moscow : Flinta : Nauka. (in Russian)

4. Hryn'kiv M. Ya., Vovkanych L.S., Muzyka F.V. (2015) Sportyvna morfolohiya (z osnovamy vikovoyi morfolohiyi) [Sports morphology (with the basics of age morphology)]. (in Ukrainian)

5. Prystupa Ye.N., Petryshyn Yu.V., Vynohrads'kyy B.A. [ta in.] (2014) Dydaktychni ihry z m'yachamy [Didactic ball games]. Lviv: LDUFK. (in Ukrainian)

6. Kravets' V.P. (2003) Henderna pedahohika [Gender pedagogy]. Ternopil': Dzhura. (in Ukrainian)

7. Lyst MON vid 02.09.2016 № 1/9-456 "Shchodo orhanizatsiyi fizkul'turno-ozdorovchoyi roboty u doshkil'nykh navchal'nykh zakladakh" [Letter of the Ministry of Education and Science dated 02.09.2016 № 1/9-456 "Regarding the organization of physical culture and health work in preschool educational institutions"]. Kiev. (in Ukrainian)

8. Lushchyk I.V. (2008) Rukhlyvi ihry v dytyachomu sadku [Moving games in kindergarten]. Kharkiv : Osnova. (in Ukrainian)

9. Lushchyk I.V. (2007) Fizychne vykhovannya doshkil'nykiv. Fizkul'turna y ozdorovcha robota [Physical education of preschoolers. Physical culture and health work]. Kharkiv : Ranok. (in Ukrainian) 
10. Pasichnyk V.M., Pitin M.P., Glukhov I.G., Drobot K.V., Glukhova G.G. (2020) Metodyka testuvannya fizychnoyi pidhotovlenosti ditey doshkil'noho viku a. c. № 100097 [Methods of testing the physical fitness of preschool children a. c. № 100097]. Kiev. (in Ukrainian)

11. Pasichnyk V. (2020) Sutnist' ihrovoyi diyal'nosti u formuvanni osobystosti ditey doshkil'noho viku [The essence of play activities in the formation of the personality of preschool children]. Sports games. № 3 (17), pp. 43-57.

12. Pozharskaya L.V. (2015) Kak uchest' osobennosti temperamenta $v$ uchebno-vospitatel'nom protsesse [How to take into account the peculiarities of temperament in the educational process]. Pedagogical workshop. Everything for the teacher. № 3 (39), pp. 6-11.

13. Runova M.O. (2007) Rukhova aktyvnist' dytyny v dytyachomu sadku [Motor activity of the child in kindergarten]. Kharkiv : Ranok. (in Ukrainian)

14. Chahovets', A.I. (2019) Harmoniyne vykhovannya ditey 4-6 rokiv u kul'turno-osvitn'omu prostori doshkil'noho navchal'noho zakladu [Harmonious education of children 4-6 years in the cultural and educational space of preschool education]. (Ph. D. Thesis), Volodymyr Dahl East Ukrainian National University.

15. Yuritsyna N.A. (2016) Uchot individual'no-tipologicheskikh osobennostey doshkol'nikov v protsesse neposredstvenno-obrazovatel'noy deyatel'nosti po fizicheskomu razvitiyu [taking into account the individual-typological characteristics of preschoolers in the process of direct educational activities for physical development]. Experimental Education Bulletin.

16. Pasichnyk V., Melnyk V., Levkiv V., Kovtsyn V. (2015) Effectiveness of integral-developmental balls use in complex development of physical and mental abilities of senior preschool age children. Journal of Physical Education and Sport. 15 (4): 775-780. DOI: 10.7752/jpes.2015.04118.

17. Pasichnyk, V., Pityn, M., Melnyk, V., Karatnyk, I., Hakman, A., \& Galan, Ya. (2018). Prerequisites for the physical development of preschool children for the realization of the tasks of physical education. Physical Activity Review, 6, 117-126.

18. Viktoria Pasichnyk, Khrystyna Khimenes, Maryan Pityn, Olha Bas, Ivan Hlukhov, Yaroslav Hnatchuk, Kateryna Drobot (2021). Physical condition of preschool children with disabilities in psychological and physical development. Journal of Physical Education and Sport (JPES), Vol. 21 (1), Art. 33, pp. 352-359. 